\title{
GATAI Gene Silencing Inhibits Invasion, Proliferation and Migration of Cholangiocarcinoma Stem Cells via Disrupting the PI3K/AKT Pathway [Retraction]
}

Shi G, Zhang H, Yu Q, Hu C, Ji Y. Onco Targets Ther. 2019; $12: 5335-5354$.

The Editor and Publisher of OncoTargets and Therapy wish to retract the published article.

The journal was notified of potential image manipulation in Figure 4D:

- Figure 4D $0 \mathrm{~h}$ panel GATA1 appears to show partial duplication with Figure 4D $0 \mathrm{~h}$ panel si-GATA1.

- Figure 4D $0 \mathrm{~h}$ si-GATA appears to show partial duplication with Figure 4D 0 h panel LY294002.
The authors could not provide the satisfactory raw data for the study and the Editor has determined the findings are no longer valid and requested for the paper to be retracted.

Our decision-making was informed by our policy on publishing ethics and integrity and the COPE guidelines on retraction.

The retracted article will remain online to maintain the scholarly record, but it will be digitally watermarked on each page as "Retracted".

\section{Publish your work in this journal}

OncoTargets and Therapy is an international, peer-reviewed, open access journal focusing on the pathological basis of all cancers, potential targets for therapy and treatment protocols employed to improve the management of cancer patients. The journal also focuses on the impact of management programs and new therapeutic agents and protocols on patient perspectives such as quality of life, adherence and satisfaction. The manuscript management system is completely online and includes a very quick and fair peer-review system, which is all easy to use. Visit http://www.dovepress.com/ testimonials.php to read real quotes from published authors. 